\title{
Ranking industries using a hybrid of DEA-TOPSIS
}

\author{
Amir Mehdiabadi ${ }^{a^{*}}$, Abolfazl Rohani ${ }^{\mathrm{b}}$, Shahram Amirabdollahiyan
}

${ }^{a}$ Young Researchers and Elite Club, Semnan Branch, Islamic Azad University, Semnan, Iran

${ }^{b}$ Lecturer Department of industrial engineering Payame Noor University, Damghan

${ }^{c}$ Young Researchers and Elite Club, Semnan Branch, Islamic Azad University, Semnan, Iran

\section{H R O N I C L E}

Article history:

Received May 12, 2013

Accepted June 22, 2013

Available online

June 302013

Keywords:

Data Envelopment Analysis

TOPSIS

$D E A$

Ranking

\begin{abstract}
A B S T R A C T
Ranking industry normally helps find hot sectors and attract potential investors to invest in appropriate plans. Ranking various industries is also a multiple criteria decision making problem. In this paper, we present an empirical investigation to rank different industries using the art of data envelopment analysis (DEA). The inputs of our proposed DEA model include capital, employment and importance coefficient and outputs are exports, ecological effects and added value. In addition, exports, value added and environmental investment are used as outputs of DEA method. Since the results of DEA may consider more than one efficient unit, so we implement Technique for Order Preference by Similarity to Ideal Solution (TOPSIS) technique to rank efficient units. In our case study, there were 15 different sectors from various industries and the implementation of DEA technique recommends 8 efficient units. The implementation of TOPSIS among these efficient units has suggested that Chemical industry could be considered as the most attracting industry for investment.
\end{abstract}

(C) 2013 Growing Science Ltd. All rights reserved.

\section{Introduction}

Measuring the relative efficiency of various industries has been a major concern among researchers for a while and there have been variety of methods and techniques to accomplish this task. Wu and Ho (2007) evaluated the productivity and efficiency of Taiwan's integrated circuit (IC) industry using data envelopment analysis (DEA) (Charnes, 1978, 1994) and the Malmquist index (MI). In this study, the Malmquist index, as a total factor productivity index based on distance functions, was evaluated using DEA. Wong and Wong (2007) used DEA method for measuring the performance of internal supply chains. Wang (2008) implemented a fuzzy multiple criteria decision making technique to evaluate financial performance of domestic airlines in Taiwan. Taner and Sezen (2009) used a hybrid of Taguchi and DEA methods to reflect the diversity of inputs and outputs by incorporating the stepwise application of sensitivity, specificity, leveling threshold, and efficiency score. They implemented their hypothetical case study on eight readers of X-ray films in clinical radiology.

* Corresponding author

E-mail addresses: amir.mehdiabadi@gmail.com (A. Mehdiabadi)

(C) 2013 Growing Science Ltd. All rights reserved.

doi: $10.5267 /$ j.dsl.2013.07.001 
Sengupta (2005) addressed an extension of the convex hull method of DEA for determining a production frontier in the presence of demand and supply uncertainty of outputs and inputs, respectively. DEA has been integrated with other useful techniques such balance score card (BSC) (Kaplan \& Norton, 1992, 1996) for measuring the relative efficiency of similar units (Rickards, 2003). De Koster et al. (2009) used DEA for benchmarking container terminals.

Technique for Order Preference by Similarity to Ideal Solution (TOPSIS) is another method for ranking different alternatives based on various criteria. The method first uses analytical hierarchy process (AHP) (Saaty, 1992) to rank criteria and then chooses a sophisticated method to rank various alternatives. TOPSIS, developed by Hwang and Yoon in 1981, is a simple but sophisticated ranking approach used in various real-world applications of science and engineering (Chang et al., 2010). The standard TOPSIS method selects alternatives, which simultaneously have the shortest distance from the positive ideal solutions and the longest distance from the negative-ideal solutions (Orougi et al., 2012). The positive ideal solution maximizes the desirable criteria and minimizes the undesirable criteria, whereas the negative ideal solution maximizes the undesirable criteria and minimizes the desirable criteria. TOPSIS makes full usage of attribute information, provides a cardinal ranking of alternatives, and does not need attribute preferences to be independent. To use this technique, attribute values must be numeric, monotonically increasing or decreasing, and have commensurable units (Chen \& Hwang, 1992; Yoon \& Hwang, 1995).

There are many applications of TOPSIS in various industries (Rostampour, 2012). Danaei and Haghighi (2013) implemented this technique for ranking different industries on Tehran Stock Exchange. They gathered the necessary data over the period of 2009-2010 from Tehran Stock Exchange and investigated the data in two stages. In the first stage, they performed fundamental analysis to select the most appropriate firms and the in the second stage, they implemented TOPSIS to rank selected firms based on various criteria. The results of the study confirmed that information and communication technology, which was one of the biggest firms in this exchange was the best option for investment (relative ranking 0.88 in two years) followed by some Cement industry (with relative ranking of 0.26 in 2009 and 0.19 in 2010) and oil refinery units (with relative ranking of 0.23 in 2009 and 0.19 in 2010). The results also showed that other firms maintained low ratios varied from 0.23 to 0.01 and the lowest industry ranking belonged to marine industry.

\section{The proposed model}

The proposed model of this paper uses standard DEA method developed by Charles et al. (1978) for ranking 16 different industries, which are active in province of Semnan, Iran.

\subsection{Data envelopment analysis}

The constant return to scale DEA (CCR) proposed by Charnes, et al. $(1978,1994)$ is a method for measuring the relative efficiency of decision making units (DMU). In this model, we form a set of production feasibility as follows,

$$
T_{C}=\left\{(X, Y) \mid X \geq \sum_{j=1}^{n} \lambda_{j} X_{j}, Y \leq \sum_{j=1}^{n} \lambda_{j} Y_{j}, \lambda_{j} \geq 0, j=1, \cdots n\right\},
$$

where $X$ and $Y$ are the input and output vectors, respectively. The CCR production feasibility set border defines the relative efficiency in which any off-border DMU is stated as inefficient. (See Chares et al., 1978, 1994 for more details). 


\subsection{TOPSIS method}

For the implementation of TOPSIS method let $x_{i j}$ be the inputs for matrix of priorities where there are $i=1, \cdots, m$ alternatives and $j=1, \cdots, n$ criteria. TOPSIS method has size step as follows,

Step 1. Form normalized decision matrix

$$
r_{i j}=\frac{x_{i j}}{\sqrt{\sum_{i=1}^{m} \sum_{j=1}^{n} x_{i j}^{2}}}
$$

Step 2. Build the weight normalized matrix

$v_{i j}=w_{i} r_{i j}, i=1, \cdots, m \quad j=1, \cdots, n$

Step 3. Calculate the positive and negative ideal solutions

$$
\begin{aligned}
& A^{+}=\left\{v_{1}^{+}, \cdots, v_{n}^{+}\right\}, \text {where } v_{j}^{+}=\left\{\max \left(v_{i j}\right) \text { if } j \in J ; \min \left(v_{i j}\right) \text { if } j \in J^{\prime}\right\} \\
& A^{-}=\left\{v_{1}^{-}, \cdots, v_{n}^{-}\right\}, \text {where } v_{j}^{*}=\left\{\min \left(v_{i j}\right) \text { if } j \in J ; \max \left(v_{i j}\right) \text { if } j \in J^{\prime}\right\}
\end{aligned}
$$

Step 4. Measure seperation (positive and negative) measures for each alternative

$$
S_{i}^{+}=\sqrt{\sum_{\mathrm{j}=1}^{\mathrm{n}}\left(v_{j}^{+}-v_{i j}\right)^{2}}, S_{i}^{-}=\sqrt{\sum_{\mathrm{j}=1}^{\mathrm{n}}\left(v_{j}^{-}-v_{i j}\right)^{2}}, i=1, \cdots, m
$$

Step 5. Finalize the relative closness to the ideal solution

$$
C_{i}^{+}=\frac{S_{i}^{-}}{S_{i}^{-}+S_{i}^{+}}, 0<C_{i}^{+}<1, i=1, \cdots, m
$$

The proposed model of this paper first uses DEA method to rank all 16 different industries and then it uses TOPSIS to rank the efficient units. Next, we present details of our findings.

\section{The results}

In this section, we first present details of our finding on the implementation of DEA technique on ranking 16 different industries. The inputs of our proposed DEA model include capital, employment and importance coefficient and outputs are exports, ecological effects and added value. In addition, exports, value added and environmental investment are used as outputs of DEA method.

Table 1 demonstrates the summary of our results. As we can observe from the results of Table 1, some of the factors are qualitative types and need to be quantified using a Likert scale (1-9) and we show these Likert numbers inside some brackets. After normalizing the information of Table 1 and applying DEA method, we find efficient and inefficient units demonstrated in Fig. 1. Note that the order of units shown on Fig. 1 is the same as shown on Table 1. In addition, there is more than one efficient unit, which creates motivation to use TOPSIS method for ranking them. 


\section{Table 1}

The inputs and outputs used for DEA model

\begin{tabular}{|c|c|c|c|c|c|c|}
\hline Industry & Capital & employment & export & $\begin{array}{l}\text { added } \\
\text { value }\end{array}$ & $\begin{array}{l}\text { Importance } \\
\text { coefficient }\end{array}$ & $\begin{array}{l}\text { ecological } \\
\text { effects }\end{array}$ \\
\hline Food industry & 169332 & 770 & 3145111 & 126675 & Middle(5) & Middle(5) \\
\hline Garment & 140336 & 454 & 47780020 & 24796 & $\operatorname{Low}(3)$ & $\operatorname{High}(7)$ \\
\hline Wood and woody production & 6612 & 109 & 0 & 5100 & Very low(1) & $\operatorname{High}(7)$ \\
\hline Paper production & 45692 & 67 & 1175739 & 15869 & $\operatorname{High}(7)$ & $\operatorname{High}(7)$ \\
\hline Coke coal industries & 76225 & 69 & 0 & 15118 & $\operatorname{High}(7)$ & Very high(9) \\
\hline Chemical Material Production & 994032 & 448 & 86766279 & 562574 & Very high(9) & Very high(9) \\
\hline Rubber and Tier products & 188399 & 316 & 13199657 & 27940 & Low(3) & Very high(9) \\
\hline Non-metallic mineral products & 408908 & 1029 & 74458796 & 195017 & Middle(5) & Very high(9) \\
\hline Production of basic metals & 119323 & 331 & 76318036 & 24961 & $\operatorname{Low}(3)$ & Very high(9) \\
\hline Original metal products & 43538 & 656 & 0 & 72948 & Middle(5) & $\operatorname{High}(7)$ \\
\hline Machinery and equipment products & 41730 & 1038 & 144204 & 119848 & Middle(5) & $\operatorname{High}(7)$ \\
\hline Machines generating electricity transmission & 99754 & 186 & 0 & 59427 & $\operatorname{High}(7)$ & Very low(1) \\
\hline Production of motor vehicles & 194956 & 425 & 152163 & 20797 & Very low(1) & Middle(5) \\
\hline Production of other transport equipment & 4845 & 120 & 0 & 14036 & Middle(5) & Middle(5) \\
\hline $\begin{array}{l}\text { production of furniture and unclassified } \\
\text { manufactures }\end{array}$ & 12340 & 268 & 0 & 40054 & Middle(5) & Middle(5) \\
\hline
\end{tabular}

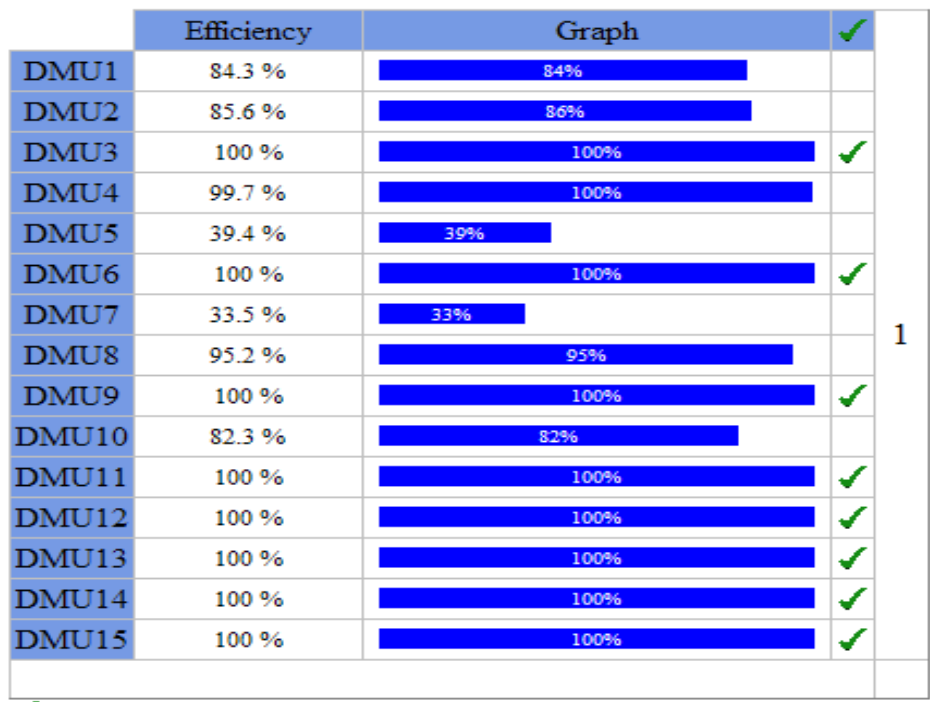

$\checkmark$ : Efficients

*: Weak Efficients

Fig. 1. The results of the implementation of DEA method

Table 2 demonstrates the results of TOPSIS ranking method using the same inputs/outputs of DEA model by considering equal weights.

Table 2

The summary of the implementation of TOPSIS method

\begin{tabular}{ccccccccc}
\hline & $\boldsymbol{M}_{\mathbf{1}}$ & $\boldsymbol{M}_{\mathbf{2}}$ & $\boldsymbol{M}_{\mathbf{3}}$ & $\boldsymbol{M}_{\mathbf{4}}$ & $\boldsymbol{M}_{\mathbf{5}}$ & $\boldsymbol{M}_{\mathbf{6}}$ & $\boldsymbol{C}_{\boldsymbol{i}}$ & Rank \\
\hline DMU3 & 0.001619338 & 0.005377654 & 0 & 0.002048565 & 0.00325793 & 0.01119626 & 0.017 & 8 \\
DMU6 & 0.243447273 & 0.022102653 & 0.265626831 & 0.225974415 & 0.02932134 & 0.00373209 & 0.501 & 1 \\
DMU9 & 0.029223263 & 0.016330308 & 0.233640515 & 0.010026321 & 0.00977378 & 0.00373209 & 0.42 & 5 \\
DMU11 & 0.029223263 & 0.016330308 & 0.233640515 & 0.010026321 & 0.00977378 & 0.00373209 & 0.5 & 2 \\
DMU12 & 0.024430641 & 0.009176548 & 0 & 0.023870605 & 0.022805 & 0.033589 & 0.452 & 3 \\
DMU13 & 0.047746457 & 0.020967919 & 0.000465833 & 0.008353728 & 0.003258 & 0.01866 & 0.441 & 4 \\
DMU14 & 0.001186584 & 0.005920354 & 0 & 0.005637973 & 0.01629 & 0.01866 & 0.406 & 6 \\
DMU15 & 0.003022176 & 0.013222123 & 0 & 0.016088869 & 0.01629 & 0.01866 & 0.132 & 7 \\
\hline
\end{tabular}




\section{Conclusion}

Ranking different industries has many advantages such as redirecting investments towards opportunities with better outlooks, attracting more people for investment, taking care of environment, etc. In this paper, we have presented an empirical investigation on ranking different industries in one Iranian province. The proposed model of this paper has implemented DEA method for ranking various industries. The results of DEA provided more than one efficient unit and the study implemented TOPSIS technique to rank the remaining efficient units. The study has concluded that Chemical industry preserved the best choice for investment purposes.

This study can be extended for more sophisticated MCDM applications. For instance, we may consider uncertainty on input/output parameters and we leave it for interested researchers as future study.

\section{References}

Charnes A, Cooper, W. W., Rhodes, E. (1978). Measuring the efficiency of decision making units. European Journal of the Operational Research, 2, 429-44.

Charnes A, Cooper W. W., Lewin, A., Seiford, L. M. (1994). Data envelopment analysis: theory, methodology and applications. Massachusetts: Kluwer Academic Publishers.

Chen, S. J., \& Hwang, C. L. (1992). Fuzzy multiple attribute decision making: Methods and applications. Berlin: Springer-Verlag.

Chang, C. H., Lin, J. J., Lin, J. H., \& Chiang, M. C. (2010). Domestic open-end equity mutual fund performance evaluation using extended TOPSIS method with different distance approaches. Expert Systems with Applications, 37, 4642-4649.

Chamodrakas, I., Alexopoulou, N., \& Martakos, D. (2009). Customer evaluation for order acceptance using a novel class of fuzzy methods based on TOPSIS. Expert Systems with Applications, 36, 7409-7415.

Danaei, A., \& Haghighi, M. (2013). Measuring the relative performance of stock market using TOPSIS. Management Science Letters, 3(1), 91-96.

De Koster, M. B. M., Balk, B. M., \& Van Nus, W. T. I. (2009). On using DEA for benchmarking container terminals. International Journal of Operations \& Production Management, 29(11), $1140-1155$.

Kaplan, R. S. \& Norton, D. P. (1992). The balanced scorecard - measures that drive performance, Harvard Business Review, 70(1), 71-79.

Kaplan, R.S. \& Norton, D.P. (1996). The balanced scorecard: translating strategy into action, Harvard Business School Press, Boston, MA.

Rao, R. V., \& Davim, J. P. (2008). A decision-making framework model for material selection using a combined multiple attribute decision-making method. The International Journal of Advanced Manufacturing Technology, 35(7-8), 751-760.

Orougi, S., Maghari, A., Mohammadi, H., Mohammadi, A \& Irani, M. (2012). An empirical investigation to use solar-geothermal hybrid energy system for small towns. Management Science Letters , 2(7), 2287-2292.

Rickards, R. C. (2003). Setting benchmarks and evaluating balanced scorecards with data envelopment analysis. Benchmarking: An International Journal, 10(3), 226-245.

Rostampour, S. (2012). An application of TOPSIS for ranking internet web browsers. Decision Science Letters, 1(2), 53-58.

Saaty, T. L. (1992). How to make a decision: the analytic hierarchy process. European Journal of Operational Research, 48, 9-26.

Sengupta, J. K. (2005). Nonparametric efficiency analysis under uncertainty using data envelopment analysis. International Journal of Production Economics, 95(1), 39-49. 
Taner, M. T., \& Sezen, B. (2009). An assessment of diagnostic efficiency by Taguchi/DEA methods. International Journal of Health Care Quality Assurance,22(1), 93-98.

Wang, Y. J. (2008). Applying FMCDM to evaluate financial performance of domestic airlines in Taiwan. Expert Systems with Applications, 34(3), 1837-1845.

Wong, W. P., \& Wong, K. Y. (2007). Supply chain performance measurement system using DEA modeling. Industrial Management \& Data Systems, 107(3), 361-381.

Wu, D. D., \& Ho, C. T. B. (2007). Productivity and efficiency analysis of Taiwan's integrated circuit industry. International Journal of Productivity and Performance Management, 56(8), 715-730.

Yoon, K. P., \& Hwang, C. L. (1995). Multiple attribute decision making. Thousand Oaks, CA: Sage Publication. 